\title{
Namibian University Entrants' Concepts of 'a Dictionary'*
}

\author{
Herman L. Beyer, Department of Language and Literature Studies \\ (hbeyer@unam.na) \\ and \\ André K. Faul, Faculty of Science (afaul@unam.na), \\ University of Namibia, Windhoek, Namibia
}

\begin{abstract}
This article reports on a survey conducted in 2009 among students registering for their first year of study at the University of Namibia. The aim of the study was to determine these school leavers' concepts of 'a dictionary' and to what extent they perceive dictionaries to be of potential help in satisfying needs for specific types of linguistic information. Furthermore, the survey attempted to determine if the variables of frequency of dictionary use, exposure to dictionary pedagogy at school and dictionary ownership had any influence on respondents' concepts of 'a dictionary'. In comparison to the literature and other similar studies, this study takes a new approach by measuring respondents' concepts of dictionaries against a pre-constructed dictionary profile based on validated assumptions while focusing on the pre-consultation situation instead of on a reflection on past dictionary consultation procedures. The findings indicate that Namibian school-leavers do not grasp the complete information potential of monolingual dictionaries. Also, although school syllabuses of language subjects require dictionary skills to be taught, about a third of the respondents were not exposed to dictionary pedagogy at school, while those respondents who were exposed to some form of dictionary pedagogy do not demonstrate a substantially different concept of dictionaries from those who did not undergo dictionary training. This result questions the quality of dictionary pedagogy where it does take place. The effects of frequency of dictionary use and dictionary ownership on respondents' concepts of dictionaries also seem to have been minimal.
\end{abstract}

Keywords: CONCEPT, DEFINITION, DICTIONARY, DICTIONARY OWNERSHIP, DICTIONARY PEDAGOGY, DICTIONARY PROFILE, DICTIONARY USER, FREQUENCY OF DICTIONARY USE, INFORMATION POTENTIAL, LEXICOGRAPHICALLY RELEVANT NEEDS, LEXICOGRAPHY, QUESTIONNAIRE, USAGE RESEARCH, USER NEEDS, USER RESEARCH

Opsomming: Namibiese universiteitstoetreders se konsepte van "'n woordeboek". Hierdie artikel doen verslag van 'n opname wat in 2009 onder eerstejaarstudente aan die Universiteit van Namibië onderneem is. Die doel van die studie was om die skoolverlaters se

* A preliminary version of this article was presented as a paper under the title ' "What is a Dictionary?" Namibian University Entrants' Perceptions' at the Fourteenth International Conference of the African Association for Lexicography, organised by the Xhosa Department of the University of the Western Cape, Bellville, South Africa, 6-8 July 2009. 
konsepte van "'n woordeboek" vas te stel en te bepaal in welke mate hulle woordeboeke beskou as potensiële hulp in die bevrediging van spesifieke tipes linguistiese inligtingsbehoeftes. Daarbenewens het die opname geprobeer om te bepaal of die veranderlikes van frekwensie van woordeboekgebruik, blootstelling aan woordeboekonderrig en woordeboekeienaarskap enige invloed op die respondente se konsepte van "'n woordeboek" gehad het. In vergelyking met die literatuur en soortgelyke opnames volg hierdie studie 'n nuwe benadering deur respondente se konsepte van woordeboeke te meet teen 'n voorafgekonstrueerde woordeboekprofiel wat op geldige veronderstellings gebaseer is terwyl die fokus op die voornaslaansituasie val in plaas van op nadenke oor vorige woordeboeknaslaanprosedures. Die bevindinge toon dat Namibiese skoolverlaters nie die volledige inligtingspotensiaal van verklarende woordeboeke besef nie. Alhoewel skoolsillabusse van taalvakke vereis dat woordeboekvaardighede onderrig word, het ongeveer 'n derde van die respondente ook nie enige vorm van woordeboekonderrig ondergaan nie, terwyl dié respondente wat wel een of ander vorm van woordeboekonderrig ondergaan het, nie ' $n$ beduidend andersoortige opvatting van woordeboeke getoon het as dié wat nie woordeboekonderrig ontvang het nie. Hierdie resultaat bevraagteken die kwaliteit van woordeboekonderrig waar dit wel plaasvind. Die effek van frekwensie van woordeboekgebruik en woordeboekeienaarskap op respondente se konsepte van woordeboeke blyk ook minimaal te wees.

Sleutelwoorde: DEFINISIE, FREKWENSIE VAN WOORDEBOEKGEBRUIK, GEBRUIKERSBEHOEFTES, GEBRUIKERSNAVORSING, GEBRUIKSNAVORSING, INLIGTINGSPOTENSIAAL, KONSEP, LEKSIKOGRAFIE, LEKSIKOGRAFIES RELEVANTE BEHOEFTES, VRAELYS, WOORDEBOEK, WOORDEBOEKEIENAARSKAP, WOORDEBOEKGEBRUIKER, WOORDEBOEKONDERRIG, WOORDEBOEKPROFIEL

Knowledge is of two kinds. We know a subject ourselves, or we know where we can find information upon it.

Samuel Johnson, 1775

\section{Introduction}

One of the noticeable features of developments in theoretical lexicography during the last two to three decades has been a strong focus on the information needs and reference skills of the target users of dictionaries (cf. e.g. Gouws and Prinsloo 2005: 5). This focus presupposes that any dictionary is compiled for a specific purpose, and that the contents and presentation of the dictionary should be directed at that specific target group (cf. e.g. Gouws 1989: 49, Hartmann 1989). This notion has led to the study of various features of dictionaries, such as dictionary functions and structures, all of which are informed by the user and the usage situation as central components of the genuine purpose of a dictionary (cf. e.g. Gouws and Prinsloo 2005: 1-8).

This article reports on a survey conducted in 2009 among students registering for their first year of study at the University of Namibia (UNAM). The aim of the study was to determine these school leavers' concepts of 'a diction- 
ary' and to what extent they perceive dictionaries to be of potential help in satisfying needs for specific types of linguistic information.

\section{Positioning and relevance}

\subsection{User research}

\subsubsection{State of the art}

Atkins and Rundell (2008: 30) describe the concept of dictionary user research as follows:

'User research' refers to any method used for finding out what people do when they consult their dictionaries, what they like and dislike about them, and what kinds of problem they look the dictionary to solve.

According to Tarp (2009: 276) interest in dictionary user research was stimulated by the conference on lexicography convened at Indiana University in November 1960 which resulted in the publication of Householder and Saporta (1967). Subsequently, Wiegand (1977) proposed the determination of a sociology of the dictionary user, to which Hartmann (1989) responded with twelve hypotheses about the dictionary user. Hartmann (1989) also reviewed the empirical user research reported up to that time in addressing his hypotheses, referring to, among others, the famous study of Barnhart (1967) and those of Quirk (1973), Béjoint (1981) and Greenbaum, Meyer and Taylor (1984), all of whose results indicate that monolingual dictionaries are first and foremost used for determining or confirming mostly meaning and secondly spelling. Since then, empirical user research has generally followed this line of enquiry and has been conducted on the basis of self-evaluation by users through the use of questionnaires, asking respondents to indicate frequency of use, information categories sought, reasons for dictionary use and the extent to which the consulted dictionaries have satisfied their needs (Jackson 2002: 76, Bogaards 2003: 26, Tarp 2009: 284-285). Recent examples of this type of empirical studies include Siegel (2007), and Ekwa Ebanéga and Moussavou (2008). Other instruments of empirical research employed to a lesser extent in user research are interviews, observation, protocols, experiments, tests and more recently log file analyses (Hartmann 2001: 115-120, Tarp 2009: 283-290).

While most empirical user research has focused on user behaviour during the actual dictionary consultation procedure, and has surveyed this behaviour mostly post hoc, Nesi (in Hartmann 2001: 117) has identified six 'stages' of dictionary consultation, each requiring different sets of skills from the user. These stages, which can be empirically investigated, are:

(a) 'before study', e.g. knowing which dictionaries exist and what information can be found in them; 
(b) 'before dictionary consultation', e.g. deciding whether consultation is necessary, which might be the problem word to be searched, and which dictionary is most likely to help;

(c) 'locating entry information', e.g. understanding the macrostructure of the dictionary (including electronic ones) and locating the problem words;

(d) 'interpreting entry information', e.g. understanding the microstructure of the dictionary, interpreting the various information categories offered within entries (including translation equivalents in bilingual dictionaries) and extracting the relevant item(s);

(e) 'recording entry information', e.g. deciding how to select, use and file the information extracted; and

(f) 'understanding lexicographical issues', e.g. awareness of dictionary terminology and conventions and the ability to evaluate entries and dictionaries.

For reviews of user research up to the present day, compare Hartmann (2001: 115-120), Atkins and Varantola (2008) and Tarp (2009).

\subsubsection{Criticism}

Substantial and valid criticism has been levelled at empirical dictionary user research. In relation to the most popular research instrument, i.e. the questionnaire, the criticism of Hatherall (1984: 184) that the data so generated provide an indication of respondents' behaviour during questionnaire administration rather than during dictionary consultation and that 'the only reliable method of collecting data on dictionary user behaviour is by direct observation,' is the most widely cited. This criticism is confirmed by Bergenholtz and Tarp (1995: 80), who state that 'it cannot be ruled out that the problems, behaviours, etc. described by the informants differ from their real problems, etc.'; Jackson (2002: 76) mentions 'a tendency to overstate and underplay' during self-reporting; and Bogaards (2003: 26) asserts that 'it is well known that what people really do may be a far cry from what they do when interviewed.' In the field of social research, from which dictionary user research seems to derive its methods, this potential skewing of the truth is also recognised (cf. e.g. Babbie and Mouton 2001: 263). However, Lew (2002) points out that this problem of the observer's paradox is not limited to questionnaires, but pertains to all direct observation techniques. Therefore, much of the criticism also applies to other instruments, all of which have their limitations.

Nevertheless, there are at least three inherent problems with surveys asking respondents to indicate which types of information they usually seek in a dictionary with a view to determine users' needs in order to improve dictionaries. Firstly, respondents have rarely undergone dictionary pedagogy and are 
at most only partially dictionary literate, which means that they are not aware of all the information categories that are at their disposal in a given dictionary (cf. Svensén 1993: 17, Hartmann 2001: 25). Siegel (2007: 30) states of the respondents in one such survey that dictionary skills had not been taught at the university where the respondents were surveyed, 'so the students would have to be learning these skills on their own'. It is then not surprising that conclusions like 'users were far from taking extensive advantage of the range of information available to them' (Algeo 1989: 31) are drawn. Secondly, and flowing from the first problem, respondents have been conditioned by previous dictionary consultation experiences to expect certain information categories in dictionaries and not to expect other information categories, leading them to consult dictionaries only when they know they would find the required information category. Consequently, conclusions such as 'the users need exactly what has already been included in dictionaries' (Tarp 2009: 291) will logically be drawn. It is therefore also understandable that Whitcut (1989: 92) reports that 'most respondents reply by describing what in their experience a dictionary is, rather than suggesting how it might be improved'. Thirdly, and flowing from the first two problems, respondents are unaware that certain existing information needs could potentially be satisfied by a dictionary if the specific information category were included in a dictionary, and consequently do not mention such needs when they are surveyed on dictionary use. In terms of Tarp (2008) these types of needs are non-recognised lexicographically relevant potential user needs.

Tarp (2009: 290-292) discusses 'a number of general problems with regard to the majority of lexicographical research projects published until now,' i.e. problems relating to sampling, the formulation of questions and data validation, and, specifically with regard to research on user behaviour during the actual dictionary consultation procedure, argues that any such survey should be conducted during the actual consultation procedures rather than post hoc. Tarp (2009: 283-290) also critically evaluates each type of instrument employed in empirical user research, the questionnaire instrument being the first to be categorically dismissed. However, Lew (2002) convincingly defends the questionnaire as a viable instrument, but stresses that its use should be well planned. This requirement obviously applies to other instruments of data collection as well.

\subsection{The present study}

\subsubsection{Background}

Any person who has access to a dictionary can be regarded as a potential dictionary user. In the modern theory of lexicographical functions (cf., e.g. Tarp 2008 - henceforth the 'Function Theory'), a distinction is made between the potential dictionary user and the actual dictionary user. These and other relevant concepts can be explained in a simplified way as follows: The potential diction- 
ary user finds him-/herself in a so-called extra-lexicographical situation, i.e. a situation wherein a dictionary is not consulted. Within this situation the potential user develops various information needs, some of which may be satisfied by consulting a dictionary. Such needs are lexicographically relevant needs, while information needs that cannot be satisfied by consulting a dictionary are lexicographically non-relevant needs. When the potential user realises that a specific need is lexicographically relevant and he/she has access to an appropriate dictionary, he/she could approach the dictionary. The moment when the potential user first selects the dictionary, he/she becomes an actual dictionary user and enters the dictionary usage situation. Within this situation the dictionary consultation procedure takes place, and when the actual user has completed the consultation and shelves the dictionary or closes the application on his/her computer, he/she leaves the dictionary usage situation and returns to the status of potential user, regardless of whether the specific user need(s) were satisfied in the lexicographical situation. (Cf. Tarp 2008: 39ff.)

One tipping point between remaining a potential dictionary user and becoming an actual dictionary user by initiating the dictionary consultation procedure is the potential user's realisation or non-realisation that a specific information need is lexicographically relevant. This implies that lexicographically relevant needs could be recognised or non-recognised (Tarp 2009: 281).

To be in a position to recognise a specific information need as lexicographically relevant, a potential user must have a certain concept of what a dictionary in general is and which information categories it can contain. If a potential user has not undergone dictionary pedagogy, recognising needs as lexicographically relevant is usually based on conditioning resulting from experience in previous dictionary usage situations (cf. 2.1.2). In certain extra-lexicographical situations, a dictionary itself could remind or even bring potential users to the insight that a particular information need is lexicographically relevant, e.g. when an integrated e-dictionary on a computer produces pop-ups while the potential user is working in a word-processing application. Obviously a printed dictionary does not have these capabilities.

Consequently, Tarp (2009: 292-293) argues that empirical research aiming at identifying user needs should focus on the extra-lexicographical situation rather than on the dictionary usage situation, and that no known user research has done exactly this.

The present study, then, seems to be the first instance of user research to indeed focus on the extra-lexicographical situation, although it is not conducted within the framework of the Function Theory (but utilises some of its terms), nor is it aimed at identifying user needs per se.

\subsubsection{Motivation, aims and objectives}

\subsubsection{Motivation}

Information is required to contribute to: 
(a) a better understanding of potential dictionary users' lexicographical frame of reference, described by Beyer (2006: 56-57) as relating to users' assumptions, habits, perceptions and attitudes with regard to dictionaries and dictionary use;

(b) the testing of assumptions with regard to a perceived lack of a dictionary culture;

(c) a more precise indication than currently exists of the extent and influence of dictionary pedagogy in Namibian schools;

(d) the establishment of a baseline for dictionary pedagogy at UNAM; and

(e) contextual knowledge with a view to planning and promoting dictionary-integrated (language) learning in Namibian schools (cf. Beyer 2010).

With regard to motivation (c), the following learning objective appears in the senior primary phase syllabus (grades 5-7) for English as a Second Language of the Ministry of Education in Namibia (Ministry of Basic Education and Culture 2000: 10-11), which also serves as the generic syllabus for all senior primary language subject syllabuses in Namibian government schools: '[Learners will] use reference materials with speed and accuracy, e.g. dictionary, atlas, directory, encyclopaedia' [sic]. The following basic competencies are listed under this learning objective:

Learners should be able to:

- arrange words alphabetically

- use a dictionary effectively to:

- find words

- use headwords (e.g. happy) to find derivatives (e.g. happiness, happily)

- find the correct spelling of a word

- find the appropriate meaning of a word

- find the word class of a word (n-noun, v-verb, adj-adjective)

- recognise idiomatic phrases and expressions

- find the correct page

- find information

In the lower primary phase syllabus (grades 1-3), no mention is made of dictionaries, although it is stated that learners should have access to 'a wide range of readers and other reading material' (Ministry of Basic Education, Sport and Culture 2004: 2). The English Second Language Syllabus for the junior secondary phase (grades 8-10) includes the following two basic competencies under learning objectives pertaining to reading, and grammar and usage respectively (Ministry of Education 2006: 11, 16):

[Learners should be able to] demonstrate the ability to find information such as meaning, spelling, idiomatic usage in dictionaries. 
[Learners should be able to] use dictionaries and other available resource books for spelling, meaning and additional information like abbreviations, idiomatic expressions, parts of speech, etc.

In the English as a Second Language Syllabus for the senior secondary phase (grades 11 and 12), a single competency statement reads that learners should be able to consult 'a dictionary for a variety of purposes' (Ministry of Education 2005: 8).

The inclusion of the respective competency statements in the syllabuses can be regarded as a ministerial directive that dictionary pedagogy should take place in Namibian government schools. This implies that school leavers should demonstrate a more than rudimentary knowledge of dictionaries as containers of linguistic information, perhaps especially those school leavers who have obtained university admission.

\subsubsection{Aims}

The aims of this study, flowing from the motivation, are to provide answers to the following research questions:

A What are Namibian university entrants' concepts of $a$ dictionary?

B How many Namibian university entrants have been exposed to some form of dictionary pedagogy?

C Does the undergoing of some form of dictionary pedagogy, frequency of dictionary use and ownership of dictionaries have an influence on Namibian university entrants' perceptions of what a dictionary is?

\subsubsection{Objectives}

The objectives of the survey, flowing from the aims of the study, are:

(a) to determine how respondents would define the concept of a dictionary;

(b) to determine if respondents possess rudimentary knowledge of dictionary typology;

(c) to determine the proportion of respondents that have been exposed to dictionary pedagogy in any form;

(d) to determine how frequently respondents used dictionaries while at school;

(e) to determine how many respondents own dictionaries;

(f) to determine respondents' recognised lexicographically relevant needs against a pre-constructed profile of lexicographically relevant needs; and 
(g) to determine if the variables contained in determinations (c), (d) and (e) have any influence on respondents' recognised lexicographically relevant needs as determined in (f).

The achievement of objectives (a), (b) and (f) would provide an answer to research question A. Research question $\mathrm{B}$ would be answered by achieving objective (c), while research question $C$ would be answered by achieving objectives (e), (f) and (g). These objectives do not pertain to users' behaviour during the dictionary consultation procedure and therefore the survey could be conducted in the extra-lexicographical situation without compromising the results.

\section{Design and execution}

\subsection{Population and sample}

\subsubsection{The population}

The population $(\mathrm{N})$ consists of (a) students who registered for their first year of study at UNAM in 2009, irrespective of the programme they were registering for, and (b) who completed their school-leaving examination in a school in Namibia. According to the Office of the Registrar at UNAM ${ }^{1}, 4023$ first year students registered at UNAM in 2009, but the computerised information system could not directly determine how many of these students, whether Namibian or not, completed their secondary education at a Namibian government school. ${ }^{2}$ To make an accurate discrimination of this nature, each first year student's record would have to be consulted. Given the sampling method employed (cf. 3.1.2.1), these steps were deemed unnecessary and therefore the exact size of the population as a subset of the 4023 first year students at UNAM in 2009 is unknown, but does not exceed 4023 individuals $(\mathrm{N}<4023)$.

\subsubsection{The sample}

\subsubsection{Sampling method}

Because of financial and time constraints, and because the members of the population are generally relatively difficult to access, a non-probability sampling method (cf. Babbie and Mouton 2001: 166) was selected for the survey. There are very few occasions when all the members of the population would be both easily accessible and willing to participate in a survey. Probably the best of these occasions would be, as is shown by Faul (2008), the registration period at the beginning of the academic year in February. At UNAM the registration procedure is largely a manual one, requiring all registering students to present themselves at the registration venue on the pre-announced registration days. During this event long queues are common and students have to wait for peri- 
ods sometimes exceeding an hour before moving to the next point, during which time they would not usually resist some form of distraction without the risk of losing their place in the queue. When specifically first year students register, there is the added advantage that, because it is their first encounter with the unknown environment of a university, they are generally cooperative.

\subsubsection{Sample type}

Given the considerations above, it was decided that a convenience sample (cf. Du Plooy 2009: 123) would be drawn from the population: Every first year student in a registration queue willing to participate in the survey would be included. Each respondent would be asked to indicate where they completed their secondary education, but discrimination would only take place during data analysis after completion of the survey, i.e. non-members of the population also participated in the survey but were disqualified post hoc and their data excluded from the study.

\subsection{Data collection method}

\subsubsection{The instrument}

Given the sample and the circumstances under which the survey were to be conducted, the self-administered questionnaire was selected as data collection instrument.

\subsubsection{Questionnaire design}

The questionnaire (cf. Addendum A) consists of direct, specific, open-ended and closed-ended questions. All closed-ended questions were multiple-choice items, some of which allowed more than one choice to be selected. Respondents were requested to indicate their choice by making an $X$ in the provided space(s) next to the selected option(s) (cf. Babbie and Mouton 2001: 233-243, Du Plooy 2009: 152-157).

The questionnaire contains 39 items. The first item was to be completed by the survey administrator and the remaining 38 items were to be completed by each respondent.

The first three items for the respondent requested biographical data: age, gender and the educational region in Namibia in which the respondents completed their secondary education. The following nine items requested data on what the respondents think a dictionary is, frequency of use at school, type of dictionary used, whether the respondents underwent dictionary pedagogy, and dictionary ownership. The remaining 27 items simulate potential dictionary consultation situations, each item stating an information need experienced by a hypothetical first year student named John and asking the respondents if they 
think John's need would be satisfied by consulting a dictionary. The data generated from these 27 items would be used to construct the respondents' profile of recognised lexicographically relevant needs, which would be compared to a pre-constructed profile of the recognised lexicographically relevant needs of a (hypothetical) dictionary literate potential user.

The questionnaire was pre-coded to facilitate computer processing, i.e. every answer in open-ended items and each variable in multiple-choice items were assigned a numeral. Post-coding would be applied in the analysis of responses to the open-ended item requesting respondents to indicate what they think a dictionary is (item 5).

\subsubsection{Administration}

The survey period ran concurrently to the 2009 first year registration period at UNAM, i.e. from 2 to 6 February 2009. Two student assistants were recruited and trained to approach potential respondents during the registration period and, upon agreement to participate, ask the respondents in which faculty they were registering. The assistants would enter this data at item $1^{3}$ and then explain the aim and working of the questionnaire to the respondents, emphasising anonymity and the fact that there are no 'wrong' answers. The respondents were then left to complete the questionnaire on their own, but they could call the assistants if any doubt with regard to an item arose. After the questionnaires had been completed, the assistants collected them and thanked the respondents for their participation.

\subsubsection{Completion rate}

During the registration period, 650 completed questionnaires were collected. Of these, 141 questionnaires were disqualified post hoc based on the item requesting the place where the respondents had completed their secondary education, leaving 509 qualifying completed questionnaires of respondents who had indicated that they had completed secondary education in Namibia $(\mathrm{n}=509)$.

This sample size represents $12.7 \%$ of the 4023 students who registered for their first year of studies at UNAM in 2009.

\subsubsection{Methods of data processing and analysis}

The coding of questionnaire items was used to feed data into a Microsoft Excel ${ }^{\circledR}$ spreadsheet for analysis. For the responses to the open-ended question which requests respondents to provide a description of what they think a dictionary is (item 5), post-coding was applied by evaluating responses as positive or negative against predetermined criteria.

The chi-square test was employed to determine statistical significance where data sets are compared. 


\section{Analysis and interpretation}

\subsection{Composition of the sample}

The sample consisted of 509 respondents (n), of which 485 indicated their gender: $175(36.1 \%)$ male and $310(63.9 \%)$ female. 486 respondents indicated their age, of which the average is 21.1 years. The distribution of the respondents across the thirteen educational regions of Namibia and the faculties at UNAM are not relevant to this particular study, though the data may become useful for comparison purposes should the study be replicated or students be grouped according to faculty in UNAM's compulsory academic literacy courses (relating to the aim of contributing to establishing a baseline for dictionary pedagogy).

To prevent language bias in their responses, the questionnaire did not ask of respondents to indicate their mother tongue.

\subsection{Respondents' concept of 'a dictionary'}

Van Sterkenburg (2003: 3) contends:

Looking for a definition of 'dictionary' is looking for a definition of the prototypical dictionary. The prototypical dictionary is the alphabetical monolingual general-purpose dictionary.

This contention is confirmed by Landau (2001: 6). Item 5 requests respondents to write in their own words what they think a dictionary is. The responses to this item would (a) indicate whether the respondents' concept of 'a dictionary' coincides with the definition of the prototypical dictionary, and (b) serve to validate the assumptions on which the rest of the survey is based.

502 respondents answered item $5(n=502)$. Each response was evaluated against two criteria that were identified as conforming to the definition of the prototypical dictionary: If a respondent's definition included reference to (a) 'words' and (b) 'their meaning' in the appropriate relation, that definition was evaluated positively, i.e. conforming to the definition of the prototypical dictionary. In this way, a definition like 'a book consisting of words and their meanings' would be evaluated positively, whereas a definition like 'a book containing words and information about them' would be evaluated negatively, even though it represents a more accurate generic definition of a dictionary. Measured against these criteria, $403(80.6 \%)$ of the 502 responses were evaluated positively. This finding supports Van Sterkenburg's definition of the prototypical dictionary and validates it as the basis for the rest of the survey.

\subsection{Frequency of dictionary use}

The item requesting respondents to indicate frequency of dictionary use at school (item 6) was answered by 500 respondents. Table 1 provides the data. 
Table 1: Frequency of dictionary use (item 6$)\left(n=500 ; X^{2}=97.6 ; d f=3 ; p<0.05\right)$

\begin{tabular}{|l|l|}
\hline Frequency of dictionary use & \% of n \\
\hline Almost every day & 38.4 \\
\hline Every week & 32.8 \\
\hline Once or twice a month & 17.8 \\
\hline Hardly ever & 11.0 \\
\hline
\end{tabular}

The most significant difference exists between the number of respondents who indicated daily dictionary use $(38.4 \%)$ and those who indicated that they 'hardly ever' consulted a dictionary $(11.0 \%)$. Added up, $71.2 \%$ of the respondents indicated that they had used a dictionary at least once a week while at school. This is obviously a very significant proportion of the sample, and might be regarded as indicative of the extent to which learners in Namibian schools experience lexicographically relevant needs every day.

Item 6 was followed up by a contingency question (item 7) requesting respondents who indicated that they 'hardly ever' used a dictionary to indicate the reason for the low frequency of use. Of the 55 respondents $(11.0 \%$ of 500$)$ who indicated 'hardly ever', 52 answered the contingency question. Table 2 provides the data.

Table 2: Reasons for 'hardly ever' consulting a dictionary (item 7) $(\mathrm{n}=52$; $\left.X^{2}=68.8 ; \mathrm{df}=4 ; \mathrm{p}<0.05\right)$

\begin{tabular}{|l|c|}
\hline Reason for 'hardly ever' consulting a dictionary & No. (\% of $\mathbf{~})$ \\
\hline No dictionaries were available. & $17(32.7)$ \\
\hline Dictionary use was not allowed in class. & $1(1.9)$ \\
\hline $\begin{array}{l}\text { There was one or only a few dictionaries, but I was afraid every- } \\
\text { one would think I was stupid if I asked to use a dictionary. }\end{array}$ & $1(1.9)$ \\
\hline I did not know how to use a dictionary. & $2(3.9)$ \\
\hline I did not find it necessary to use a dictionary. & $31(60.0)$ \\
\hline
\end{tabular}

It is significant that most respondents who had indicated 'hardly ever' using a dictionary indicated as reason that they did not consider dictionary consultation necessary. A motivation for this behaviour might be that they are less aware of their lexicographically relevant needs than those respondents who indicated higher frequencies of dictionary consultation. The unfortunate lack of resources in many Namibian schools would account for the fact that about a third of the respondents indicated that no dictionaries were available.

\subsection{Knowledge of dictionary typology}

Respondents' knowledge of dictionary typology was measured with item 8, asking the respondents to indicate 'what kind of dictionary' they used at school. 
This item was answered by 493 respondents $(n=493)$. Table 3 summarises the data.

Table 3: Type of dictionary usually consulted (item 8$)\left(n=493 ; X^{2}=613.5\right.$; $\mathrm{df}=2 ; \mathrm{p}<0.05)$

\begin{tabular}{|l|r|}
\hline Type of dictionary usually consulted & \% of n \\
\hline Monolingual dictionary & 85.6 \\
\hline Bilingual dictionary & 10.2 \\
\hline Don't know & 4.2 \\
\hline
\end{tabular}

It is significant that the overwhelming majority of respondents indicated that they had used monolingual dictionaries, while a very small minority admitted to not knowing what type of dictionary they had used. The figures relating to this distinction represents a very rough and basic idea of respondents' awareness of dictionary typology, which might have been influenced by the absence of an 'other (specify)' variable in the item. It can therefore be deduced that by far most respondents seem to be aware that at least two types of dictionaries exist, i.e. monolingual and bilingual dictionaries. The most probable reasons for the significantly low use of bilingual dictionaries is that many of the 'African' languages in Namibia either have no bilingual dictionaries with English, or the ones that do exist are of such inferior quality that they are virtually useless in potential usage situations. A welcome and modern exception is A Khoekhoegowab Dictionary with an English Khoekhoegowab Index (Haacke and Eiseb 2002). Such dictionaries would however be used almost exclusively in the relevant language class where the actual language is studied. In all other subjects, English is the medium of instruction (from grade 4 onwards) and the use of English monolingual dictionaries especially for text reception purposes can be assumed (but would have to be confirmed by empirical research). Also, for most of the 'African' languages in Namibia no monolingual dictionaries exist as yet.

To determine which dictionaries are popular among respondents (and schools), they were asked to indicate the title of the dictionary they usually used at school (item 9). This item was answered by 459 respondents $(n=459)$. It contained an open-ended question, but respondents were given the option to enter "don't remember'. Table 4 shows those titles indicated by more than $1 \%$ of the respondents. They are given as they have been provided by respondents, although some have been interpreted and grouped with others, as is indicated by the use of brackets.

Table 4: Titles of dictionaries usually used at school by more than $1 \%$ of the respondents (item 9) $(n=459)$

\begin{tabular}{|l|c|}
\hline Dictionary 'title' & \% of $\mathbf{~}$ \\
\hline Oxford (Dictionary) & 58.0 \\
\hline 'Don't remember' & 24.8 \\
\hline
\end{tabular}




\begin{tabular}{|l|l|}
\hline Oxford (Advanced Learner's Dictionary) & 3.5 \\
\hline Cambridge (Advanced Learner's) (Dictionary) & 3.0 \\
\hline Active (English) Dictionary & 2.6 \\
\hline Oxford School Dictionary & 1.7 \\
\hline Longman (Dictionary) & 1.5 \\
\hline (Longman) Contemporary English Dictionary & 1.3 \\
\hline Oxford (English) Pocket Dictionary & 1.3 \\
\hline
\end{tabular}

The results in Table 4 reflect the commercial reality in Namibia with regard to dictionaries: The dictionaries of Oxford University Press (OUP) dominate the reference sections in all bookshops in Windhoek and most bookshops in other towns. It is therefore not surprising that the vast majority of respondents seem to have used some Oxford ${ }^{\circledR}$ dictionary or other, regardless of whether it is the ideal dictionary to satisfy the potential users' information needs. Consequently, the fact that most respondents have indicated that they had used an Oxford ${ }^{\circledR}$ dictionary at school should not be interpreted as reflecting the success with which these dictionaries satisfy their lexicographical needs, nor that the Namibian education authorities prefer these dictionaries above others based on lexicographical merits. Rather, it indicates the effect of OUP's marketing efforts in Namibia. Dictionary publishers in South Africa generally view the size of the Namibian market as negligible. Therefore not all publishers market their lexicographical products with equal vigour in the country. Owing to space considerations, the effects of this attitude will not be elaborated on here.

It is interesting that $24.8 \%$ of the respondents did not remember the title of the dictionary they used at school. There could be various explanations for this phenomenon, none of which, however, can be argued for conclusively within the limits of this study.

\subsection{Dictionary pedagogy}

Item 10 requested respondents to indicate whether they had received any form of dictionary pedagogy at school. The item was answered by 505 respondents, of which $60.8 \%$ indicated that they had been 'taught' how to use a dictionary, while $39.2 \%$ indicated that they had not undergone dictionary pedagogy $\left(\mathrm{n}=505 ; X^{2}=24.5 ; \mathrm{df}=1 ; \mathrm{p}<0.05\right)$.

Respondents who indicated that they had been 'taught' dictionary skills were subsequently asked whether these skills were taught to them by a language teacher or another teacher (item 11). All 308 of these respondents $(60.8 \%$ of 505) answered this question, of which $94.2 \%$ indicated that they had been 'taught' dictionary skills by a language teacher, while the remaining $5.8 \%$ indicated that another teacher had 'taught' them dictionary skills $(\mathrm{n}=308$; $\left.X^{2}=240.2 ; \mathrm{df}=1 ; \mathrm{p}<0.05\right)$.

It is significant that the vast majority of respondents had undergone some 
form of dictionary pedagogy, and that in the vast majority of these cases the language teacher had been the instructor. This indicates a certain level of compliance with the language syllabus requirements, but leaves cause for concern about the unduly large proportion of respondents (39.2\%) who were not exposed to dictionary pedagogy in spite of syllabus requirements, and therefore had to achieve the relevant competencies on their own. This may be due to a lack of resources, teachers' own lack of dictionary skills and/or their indifference or even aversion to dictionary use, as reported by, among others, Béjoint (1989: 208-209), Carstens 1995 (106-109), Bogaards (2003: 28) and Kernerman (2007: 141).

\subsection{Dictionary ownership}

Item 12 requested respondents to indicate whether they own a dictionary. The item was answered by 474 respondents, of whom $74.3 \%$ indicated that they do own a dictionary and the remaining $25.7 \%$ indicated that they do not $(\mathrm{n}=474$; $\left.X^{2}=111.6 ; \mathrm{df}=1 ; \mathrm{p}<0.05\right)$.

It is significant that a substantially larger proportion of the respondents owns dictionaries, compared to the proportion that does not own dictionaries. At first glance this is a somewhat surprising result, as such a high level of dictionary ownership was not expected against the background of a virtually absent reading culture in Namibia (cf. Tötemeyer 2010). However, it should be borne in mind that English is the only official language in Namibia while it was spoken as mother tongue by only $0.8 \%$ of the Namibian population in 1991 (Maho 1998: 166), and that from grade 4 onwards English is phased in as the main medium of instruction in government schools until being the sole medium of instruction by grade 8 (Ministry of Education and Culture 1993: 67). In this context, the relatively high level of dictionary ownership can be regarded as a clear indication of the significance respondents attach to their own experiences of lexicographically relevant needs, probably with regard to English. Whether these respondents own the appropriate dictionaries for satisfying these needs, however, is a completely different question - one that this survey does not aim to answer. What becomes clear from this and the previous items, though, is that a significant level of recognised lexicographically relevant needs do exist among the respondents, and that it is probably safe to assume that these needs would almost invariably originate in educational situations.

\subsection{Recognised lexicographically relevant needs}

Respondents' recognised lexicographically relevant needs were tested by items 13 to 39. For every item, respondents are presented with a statement about an information need experienced by a student named John. Following each statement, respondents are asked to indicate whether they thought a dictionary 
would satisfy the relevant information need by answering 'yes', 'no' or 'don't know'. A summary of the results of these items appears in Addendum B.

Among the 27 items, seven unevenly distributed items are included to which respondents' answers should be 'no' if they demonstrate an accurate understanding of what a dictionary is, i.e. if they provided at least the prototypical definition (see 4.2) of a dictionary in item 4. These items are items 14 (i.e. 'John wonders how the weather will be like tomorrow. Do you think a dictionary would provide the answer?'), 17, 21, 26, 28, 32 and 36. A summary of the results of these items (as an extract of Addendum B) appears in Table 5 below.

Table 5: Summary of results of items 14, 17, 21, 26, 28, 32 and 36

\begin{tabular}{|c|c|c|c|c|c|c|c|}
\hline Item no. & Yes $\%$ & No \% & Don't know \% & $\mathbf{n}$ & $\boldsymbol{X}^{2}$ & $\mathbf{d f}$ & $\mathbf{p}$ \\
\hline 14 & 1.0 & 99.0 & 0.0 & 501 & 972.3 & 2 & $<0.05$ \\
\hline 17 & 1.6 & 97.4 & 1.0 & 501 & 925.5 & 2 & $<0.05$ \\
\hline 21 & 1.9 & 97.5 & 0.6 & 476 & 881.5 & 2 & $<0.05$ \\
\hline 26 & 1.2 & 97.1 & 1.7 & 481 & 879.8 & 2 & $<0.05$ \\
\hline 28 & 11.5 & 79.5 & 9.0 & 478 & 458.9 & 2 & $<0.05$ \\
\hline 32 & 1.4 & 96.9 & 1.7 & 478 & 868.1 & 2 & $<0.05$ \\
\hline 36 & 1.0 & 98.2 & 0.8 & 496 & 938.7 & 2 & $<0.05$ \\
\hline
\end{tabular}

On average $95.1 \%$ of the respondents (n) answered 'no' to the items in Table 5, which can be regarded as an indication of the validity of the results of items 13 to 39 .

The comparatively high number of 'yes' answers to item $28(11.5 \%)$ is interesting, and it is conceivable that some dictionaries might in fact satisfy the information need of why Christmas falls on 25 December by including the relevant encyclopaedic data. For this survey, however, this data type is excluded as a lexicographical data type.

The remaining 20 items represent different data categories that are usually found in monolingual (learner's) dictionaries. The fact that the vast majority of the respondents' definitions of 'a dictionary' (80.6\%) conform to the definition of the prototypical dictionary, confirms that this approach corresponds optimally to the most probable concept that the respondents have of a dictionary. These items will henceforth be called the lexicographically valid items. Table 6 below indicates the relevant data category represented by each lexicographically valid item.

Table 6: Data categories represented by the lexicographically valid items

\begin{tabular}{|c|l|c|l|}
\hline Item no. & Data category & Item no. & Data category \\
\hline 13 & spelling & 27 & morphology: verb tense \\
\hline 15 & meaning & 29 & meaning of an abbreviation \\
\hline
\end{tabular}




\begin{tabular}{|l|l|c|l|}
\hline 16 & pronunciation & 30 & syntagmatic lexical relation \\
\hline 18 & break-off of word & 31 & meaning \\
\hline 19 & morphology: plural formation & 33 & part of speech \\
\hline 20 & meaning of an idiom & 34 & lexical relation: opposite \\
\hline 22 & fixed preposition (collocation) & 35 & lexical relation: synonym \\
\hline 23 & sociostylistic markedness & 37 & sociostylistic markedness \\
\hline 24 & spelling: capitalisation & 38 & punctuation \\
\hline 25 & etymology & 39 & subject-verb agreement \\
\hline
\end{tabular}

The responses to these items were used to measure the respondents' recognised lexicographically relevant needs in two ways, namely (a) by calculating the average respondent score, and (b) by comparing responses to individual lexicographically valid items and the represented data categories.

\subsubsection{Average respondent score}

The data categories represented by the lexicographically valid items constitute a pre-constructed dictionary profile against which the respondents' concepts of 'a dictionary' can be measured. The average respondent score is determined by calculating the average percentage of 'yes' responses to all the lexicographically valid items. An average score of $100 \%$ would mean a 100\% correspondence between the pre-constructed dictionary profile and the respondents' average concepts of 'a dictionary'.

When the percentages of 'yes' responses to the lexicographically valid items in Addendum B are taken, the average respondent score is calculated as $66.5 \%$. It can therefore be stated that, on average, the respondents' concepts of 'a dictionary' correspond at $66.5 \%$ to the pre-constructed dictionary profile. If the pre-constructed dictionary profile is accepted as a general dictionary profile, the result can be generalised to the effect that the respondents on average recognise $66.5 \%$ of the information potential of dictionaries, which represents their recognised lexicographically relevant needs relative to the general dictionary profile. Conversely, $33.5 \%$ of the information potential of dictionaries is not recognised by the respondents, which represents their non-recognised lexicographically relevant needs relative to the general dictionary profile.

\subsubsection{Responses to individual lexicographically valid items}

An overview of the responses to the lexicographically valid items, as a representation of the relevant data in Addendum B, is presented in Figure 1.

Because of space constraints only the most salient features of the results will be pointed out. The presentation of the data allows the reader to study the results in detail. 


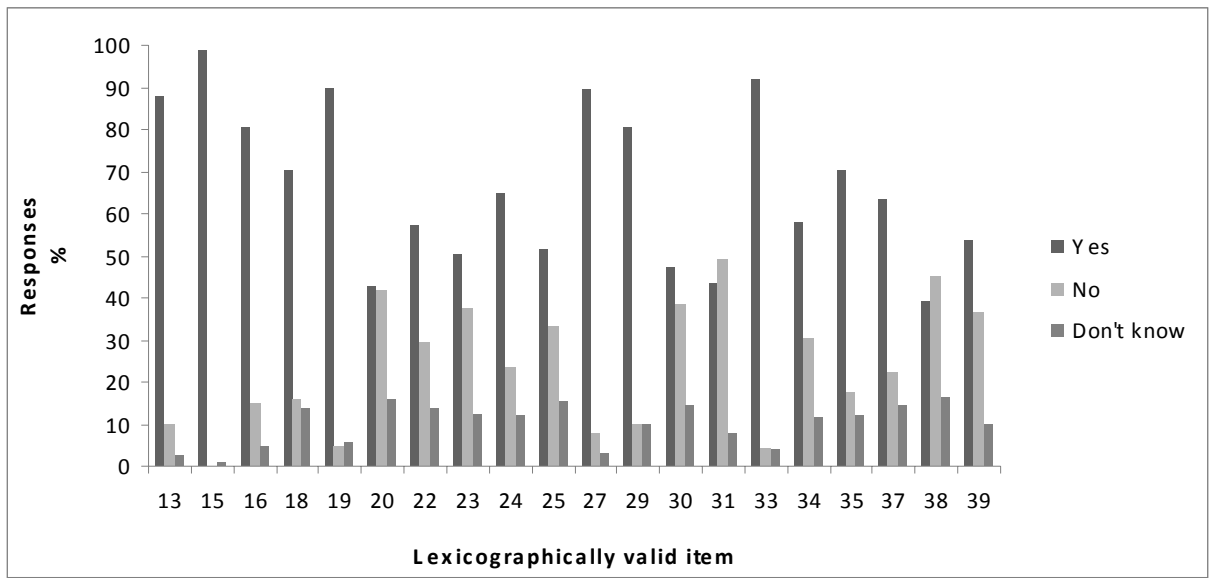

Figure 1: Bar graph showing responses to individual lexicographically valid items

The items recognised as representing lexicographically relevant needs by more than $80 \%$ of the respondents are indicated in descending order in Table 7.

Table 7: Lexicographically valid items receiving more than $80 \%$ 'yes' answers

\begin{tabular}{|c|l|c|}
\hline Position & Data category (item) & \% 'yes' answers \\
\hline 1 & meaning (15) & 98.8 \\
\hline 2 & part of speech identification (33) & 91.8 \\
\hline 3 & morphological information: plural formation (19) & 89.7 \\
\hline 4 & morphological information: verb tense (27) & 89.4 \\
\hline 5 & spelling (13) & 87.8 \\
\hline 6 & meaning of abbreviation (29) & 80.6 \\
\hline 7 & pronunciation (16) & 80.5 \\
\hline
\end{tabular}

The items recognised as representing lexicographically relevant needs by less than $50 \%$ of the respondents are indicated in ascending order in Table 8.

Table 8: Lexicographically valid items receiving less than 50\% 'yes' answers

\begin{tabular}{|c|l|c|}
\hline Position & Data category (item) & \% 'yes' answers \\
\hline 1 & punctuation (38) & 39.1 \\
\hline 2 & meaning of idioms (20) & 42.5 \\
\hline 3 & meaning (31) & 43.6 \\
\hline 4 & syntagmatic lexical relations (30) & 47.2 \\
\hline
\end{tabular}


The first and most noticeable feature of the results in Table 7 and Table 8 is that the data category of meaning was recognised as lexicographically relevant by $98.8 \%$ of the respondents as represented by item 15 but only by $42.5 \%$ of the respondents as represented by item 31 . Item 31 also yielded the most 'no' answers of the lexicographically valid items (43.6\%). This apparent anomaly demands a closer look at the statements contained in the items involved:

Item 15: John wonders what the meaning of the word courteous is.

Item 31: John wonders how many eggs are in a dozen: 10 eggs or 12 eggs?

While the statement in item 15 can be regarded as referring directly to meaning, the statement in item 31 might not be seen by all respondents as relating to meaning. It can be argued that what is at stake in item 31 is a single semantic component of the meaning of the lexical item dozen and not its entire meaning. Had the statement read 'John wonders what the meaning of the word dozen is', the result would in all probability have compared favourably to that of item 15 . Nevertheless, this anomaly provides an important insight for dictionary pedagogy: Although the need for information on the meaning of a word is clearly the most widely recognised lexicographically relevant need, as this study and those referred to in 2.1.1 confirm, the concept meaning and its application cannot be assumed to be identical for all potential dictionary users. During dictionary pedagogy it might not be sufficient to merely state that a dictionary (also) provides the meaning of words and to task learners during related exercises to 'find the meaning' of a given word. The full scope of the concept meaning should be explored, so that potential dictionary users would in the first place recognise a relevant need for information as one pertaining to (an aspect of) meaning, failing which, they would not recognise such a need as lexicographically relevant, as the results of item 31 seem to suggest.

The second noticeable feature of the results in Table 7 is that the data categories of part of speech identification and morphological information on plural formation and verb tense scored higher as recognised lexicographically relevant needs than spelling, which other user studies have ranked as the second most consulted data category (cf. Hartmann 1989). When the dictionary 'titles' provided by respondents in answering item 9 (cf. 4.4) are considered, the most probable reason for this difference is that the respondents used dictionaries to satisfy mostly second language information needs whereas the results referred to by Hartmann pertain to mother tongue information needs.

The items that were recognised as representing lexicographically relevant needs by between $50 \%$ and $80 \%$ of the respondents were items 18 (break-off of a word), 22 (indication of a fixed preposition), 23 (sociostylistic markedness), 24 (spelling: capitalisation), 25 (etymology), 34 (indication of an opposite), 35 (indication of a synonym), 37 (sociostylistic markedness) and 39 (subject-verb agreement). 
4.8 Recognised lexicographically relevant needs vs. exposure to dictionary pedagogy at school, frequency of dictionary use or dictionary ownership

To determine if the variables of exposure to dictionary pedagogy at school, frequency of dictionary use or dictionary ownership had an effect on respondents' recognised lexicographically relevant needs relative to the pre-constructed dictionary profile, the results of two calculations are presented: (a) comparisons between the relevant average respondent scores (cf. 4.7.1) and (b) comparisons between the responses to the lexicographically valid items.

\subsubsection{Compared average respondent scores for all variables}

No statistically significant difference was found between the average respondent scores for any of the variables. This means that the variables of exposure to dictionary pedagogy, frequency of dictionary use and dictionary ownership had no significant effect on respondents' average scores in relation to the preconstructed dictionary profile.

\subsubsection{Responses to lexicographically valid items vs. exposure to dictionary pedagogy}

The results of this comparison show that there are statistically significant differences between the two groups of responses only with regard to five of the twenty lexicographically valid items $(p<0.05)$. These results are summarised in Table 9.

Table 9: Lexicographically valid items yielding statistically significant differences between the answers of respondents who had undergone dictionary pedagogy at school and those who had not

\begin{tabular}{|c|l|c|c|c|l|l|l|l|}
\hline Item no. & Taught? & Yes \% & No \% & Don't know \% & n & $\boldsymbol{X}^{2}$ & df & p \\
\hline \multirow{2}{*}{13} & Yes & 90.8 & 6.9 & 2.3 & 305 & \multirow{2}{*}{7.2} & 2 & \multirow{2}{*}{0.03} \\
& No & 83.0 & 13.9 & 3.1 & 194 & & & \\
\hline \multirow{2}{*}{22} & Yes & 61.8 & 25.1 & 13.1 & 283 & \multirow{2}{*}{8.2} & 2 & \multirow{2}{*}{0.02} \\
& No & 48.9 & 36.0 & 15.1 & 186 & & & \\
\hline \multirow{2}{*}{24} & Yes & 69.4 & 19.4 & 11.2 & 284 & 7.9 & 2 & \multirow{2}{*}{0.02} \\
& No & 57.3 & 29.7 & 13.0 & 185 & & & \\
\hline \multirow{2}{*}{29} & Yes & 80.8 & 7.7 & 11.5 & 287 & \multirow{2}{*}{6.8} & 2 & \multirow{2}{*}{0.03} \\
& No & 80.1 & 13.4 & 6.5 & 186 & & & \\
\multirow{2}{*}{34} & Yes & 59.3 & 26.8 & 13.9 & 287 & \multirow{2}{*}{6.5} & 2 & \multirow{2}{*}{0.04} \\
& No & 55.1 & 36.4 & 8.5 & 187 & & & \\
\hline
\end{tabular}


The represented data categories are spelling (items 13 and 24), the indication of a fixed preposition (collocation) (item 22), the meaning of an abbreviation (item 29 ) and the indication of an opposite (item 28). With regard to the items pertaining to spelling, the statistical significant difference occurs with regard to the number of 'yes' answers, i.e. significantly more respondents who had undergone dictionary pedagogy at school recognised spelling as a lexicographically relevant need than those who had not been exposed to dictionary pedagogy. The same applies to the item representing the indication of a fixed preposition. With regard to the items representing an indication of the meaning of an abbreviation and the indication of an opposite, the statistically significant difference occurs in relation to the number of 'no' answers, i.e. significantly more respondents who had not undergone dictionary pedagogy denied these data categories as lexicographically relevant needs than those who had indeed been exposed to dictionary pedagogy.

Overall, exposure to dictionary pedagogy seems to have had a significant effect on respondents' evaluation of specific information needs as lexicographically relevant with regard to five $(25 \%)$ of the twenty lexicographically valid items. These recognised lexicographically relevant needs correspond to a certain extent to the competency statements in the relevant school syllabuses (cf. 2.2.2.1).

\subsection{Responses to lexicographically valid items vs. frequency of dictionary use}

When responses to lexicographically valid items according to frequency of dictionary use are compared, six of the lexicographically valid items yielded significantly different results $(\mathrm{p}<0.05)$. These results are summarised in Table 10.

Table 10: Lexicographically valid items yielding statistically significant differences in terms of frequency of dictionary use

\begin{tabular}{|c|l|r|c|c|r|c|c|c|}
\hline Item no. & $\begin{array}{l}\text { Frequency } \\
\text { of use }\end{array}$ & Yes \% & No \% & Don't know \% & $\mathbf{n}$ & $\mathbf{X}^{\mathbf{2}}$ & $\mathbf{d f}$ & $\mathbf{p}$ \\
\hline \multirow{5}{*}{15} & Daily & 99.5 & 0.0 & 0.5 & 189 & & & \\
& Weekly & 100.0 & 0.0 & 0.0 & 162 & 17.1 & 6 & 0.01 \\
& Monthly & 100.0 & 0.0 & 0.0 & 88 & & & \\
& Rarely & 90.7 & 1.9 & 7.4 & 54 & & & \\
\hline \multirow{5}{*}{19} & Daily & 91.5 & 5.1 & 3.4 & 177 & & & \\
& Weekly & 91.6 & 2.6 & 5.8 & 154 & 17.3 & 6 & 0.01 \\
& Monthly & 86.2 & 9.2 & 4.6 & 87 & & & \\
& Rarely & 82.4 & 2.0 & 15.6 & 51 & & & \\
\hline \multirow{5}{*}{22} & Daily & 65.6 & 23.7 & 10.7 & 177 & & & \\
& Weekly & 54.6 & 29.2 & 16.2 & 154 & 14.1 & 6 & 0.028 \\
& Monthly & 51.2 & 38.4 & 10.4 & 86 & & & \\
& Rarely & 44.0 & 34.0 & 22.0 & 50 & & & \\
\hline
\end{tabular}




\begin{tabular}{|c|l|r|r|r|r|l|l|l|}
\hline \multirow{3}{*}{29} & Daily & 85.2 & 5.5 & 9.3 & 182 & & & \\
& Weekly & 79.9 & 10.1 & 10.0 & 149 & 26.1 & 6 & 0.0002 \\
& Monthly & 85.2 & 11.4 & 3.4 & 88 & & & \\
\hline \multirow{3}{*}{33} & Rarely & 56.9 & 21.6 & 21.5 & 51 & & & \\
\hline \multirow{5}{*}{39} & Daily & 95.1 & 1.6 & 3.3 & 182 & & & \\
& Weekly & 91.9 & 4.7 & 3.4 & 148 & 19.9 & 6 & 0.003 \\
& Monthly & 92.1 & 3.4 & 4.5 & 89 & & & \\
& Rarely & 78.4 & 15.7 & 5.9 & 51 & & & \\
\hline \multirow{5}{*}{ Daily } & 61.5 & 28.9 & 9.6 & 187 & & & \\
& Weekly & 52.2 & 41.4 & 6.4 & 157 & 14.5 & 6 & 0.02 \\
& Monthly & 46.6 & 39.8 & 13.6 & 88 & & & \\
\hline
\end{tabular}

The two items yielding the greatest statistically significant differences are item $29(\mathrm{p}=0.0002)$ and item $33(\mathrm{p}=0.003)$. These items represent the data categories of meaning of an abbreviation and part of speech identification respectively. In terms of item 29 , significantly fewer respondents who indicated that they had rarely used a dictionary at school answered 'yes' and significantly more 'no' and 'don't know' than those who indicated more frequent dictionary use. This leads to the conclusion that significantly more respondents who had used dictionaries at least once a month recognised the need for information on the meaning of an abbreviation as a lexicographically relevant need than those who had rarely used a dictionary. A similar result applies to item 33 with respect to recognising the need for information on part of speech as lexicographically relevant, except that the differences are only significant in terms of the 'yes' and 'no' answers.

The results of item 15 indicate that significantly more respondents who had used a dictionary rarely were unsure of whether needs for information on the meaning of words were lexicographically relevant than those who had more frequently used a dictionary and answered 'don't know' (7.4\% as opposed to $0.5 \%$ and lower). Also, significantly fewer respondents who indicated rare dictionary use confirmed this need as lexicographically relevant by answering 'yes' (90.7\% as opposed to $99.5 \%$ and higher), although the absolute result remains very high.

Significantly more respondents who indicated rare dictionary use were unsure whether a need for information on the formation of plural forms represents a lexicographically relevant need and answered 'don't know' than those who indicated more frequent dictionary use (item 19: 15.6\% as opposed to $5.8 \%$ and lower).

With regard to item 22, significantly more respondents who indicated daily dictionary use confirmed a need for information on a collocation as lexicographically relevant than those who indicated less frequent dictionary use (65.6\% as opposed to $54.6 \%$ and lower). Also, significantly more respondents who indicated rare dictionary use were unsure of the status of this information 
need than those who indicated more frequent dictionary use (22.0\% as opposed to $16.2 \%$ and lower). Generally, however, the need for information on collocations are regarded as lexicographically relevant by only $65.6 \%$ of respondents who indicated daily dictionary use, and declines with decreased frequency of dictionary use.

The results to item 39 shows a clear decrease in the number of 'yes' answers with a decrease in dictionary use frequency (daily $61.5 \%$ to rarely $40.8 \%$ ), suggesting that significantly more respondents who indicated daily dictionary use recognised a need for information on subject-verb agreement as lexicographically significant than those who indicated less frequent dictionary use.

Generally, the results described above indicate that more respondents who used dictionaries frequently recognised the mentioned needs as lexicographically relevant than those who used dictionaries less frequently. This is the case with six $(30 \%)$ of the twenty lexicographically valid items.

\subsection{Responses to lexicographically valid items vs. dictionary ownership}

In comparing responses to lexicographically valid items according to dictionary ownership, only two of the lexicographically valid items yielded significantly different results $(p<0.05)$. These results are summarised in Table 11.

Table 11: Lexicographically valid items yielding statistically significant differences in terms of dictionary ownership

\begin{tabular}{|c|l|c|c|c|c|c|c|c|}
\hline Item no. & $\begin{array}{c}\text { Owner of } \\
\text { dictionary? }\end{array}$ & Yes \% & No \% & Don't know \% & $\mathbf{n}$ & $\mathbf{X}^{2}$ & $\mathbf{d f}$ & $\mathbf{p}$ \\
\hline \multirow{2}{*}{19} & Yes & 91.8 & 3.0 & 5.2 & 330 & 2.6 & 2 & 0.008 \\
& No & 82.6 & 9.6 & 7.8 & 115 & & \\
\hline \multirow{2}{*}{37} & Yes & 66.5 & 21.5 & 12.0 & 343 & 7.8 & 2 & 0.02 \\
& No & 54.3 & 24.1 & 21.6 & 116 & & \\
\hline
\end{tabular}

In terms of item 19, significantly more respondents who own dictionaries recognised a need for information on plural formation as lexicographically relevant and answered 'yes' than did respondents who do not own dictionaries $(91.8 \%$ vs. $82.6 \%)$. Conversely, significantly more respondents who indicated that they do not own a dictionary denied this need as lexicographically relevant and answered 'no' than did respondents who indicated that they own a dictionary (9.6\% vs. $3.0 \%)$.

With regard to item 37, significantly more respondents who own dictionaries recognised a need for pragmatic information on a word as lexicographically relevant and answered 'yes' than did respondents who do not own dictionaries ( $66.5 \%$ vs. $54.3 \%$ ). Also, significantly more respondents who indicated that they do not own a dictionary were unsure whether this need is lexicographically relevant and answered 'don't know' than did respondents who indicated that they own a dictionary (21.6\% vs. $12.0 \%)$. 
Overall, dictionary ownership as a variable seems to have had a significant effect on respondents' evaluation of specific information needs as lexicographically relevant with regard to two $(10 \%)$ of the twenty lexicographically valid items.

\section{Conclusions}

The results discussed above have addressed the objectives of the survey as set out in 2.2.2.3. In terms of the aims of the study, the following conclusions, as answers to the research questions in 2.2.2.2, can be formulated:

A Generally, the respondents' perceptions of 'a dictionary' coincides with a prototypical definition of the concept dictionary as 'a source providing the meaning of words', and in line with this perception respondents demonstrate a rudimentary knowledge of dictionary typology.

B In spite of the syllabus requirements of the Namibian Ministry of Education, only $60.8 \%$ of the respondents had been exposed to some form of dictionary pedagogy at school.

C (1) Dictionary pedagogy at school has had a minimal effect $(25 \%)$ on respondents in terms of recognising specific needs for information in the survey as lexicographically relevant. In terms of the average concept respondents have of the information potential of a dictionary, it seems that dictionary pedagogy at school has had no effect.

(2) Frequency of dictionary use has had some effect (30\%) on respondents in terms of recognising specific needs for information in the survey as lexicographically relevant. In fact, it seems that frequency of dictionary use has had a marginally greater effect in this respect than dictionary pedagogy. In terms of the average concept respondents have of the information potential of a dictionary, it seems that frequency of dictionary use has had no effect.

(3) Dictionary ownership has had a negligible effect $(10 \%)$ on respondents in terms of recognising specific needs for information in the survey as lexicographically relevant. In terms of the average concept respondents have of the information potential of a dictionary, it seems that dictionary ownership has had no effect.

\section{Limitations of the study}

The following limitations apply to this study, and offer avenues for further research:

(a) Because of the sample type, the results of the survey cannot be generalised for the whole population. However, the sample is fairly substantial 
in size $(n=509)$, providing at least some level of confidence in its representatives. To acquire results that could be applied to the whole population, either replications of the survey (cf. Du Plooy 2009: 122) or complementing data gathering methods would have to be employed (cf. Lew 2002).

(b) The quality of dictionary pedagogy as a variable is not accounted for. The general assumption, however, based on the results of the survey, knowledge of teacher training curricula and experience with in-service teacher training, is that dictionary pedagogy at schools would be offered at an extremely basic level and in a non-systematic fashion. This could probably be attributed to teachers' own insecurities and attitudes, as referred to in 4.5 .

(c) Although the lexicographically valid items in the questionnaire are said to be representing data categories, the exact level of representation is not accounted for. This, however, does not influence the relative results. As was seen in the different responses to items 13 and 31, both said to represent the data category of indication of meaning, the formulation of items might have an influence on responses. This possible influence could be accounted for by including more (control) items representing a single data category.

\section{Perspective}

This perspective is offered as a response to the motivation for this study (cf. 2.2.2.1).

The concepts the respondents have of 'a dictionary' resemble the concept of the prototypical dictionary.

Carstens (1995: 107) states that school learners display an aversion to dictionary use. This observation seems to be challenged by the fact that $38.4 \%$ of the respondents in this study reported daily dictionary use and a further 32.8\% weekly dictionary use at school, while $74.3 \%$ of the respondents own dictionaries. One reason for the apparent inconsistency between Carstens' statement and the data could be that, while Carstens' statement applies to the South African context, the educational context in Namibia causes comparatively more (acute) needs for linguistic information among learners. Another, perhaps less probable reason could be that learners' attitudes to dictionaries and dictionary use have changed significantly over the past fifteen years.

It is generally accepted that no dictionary culture exists in South Africa, and the same can probably be said of Namibia. However, when the frequency of dictionary use and the levels of dictionary ownership revealed by the survey are considered, at least some prerequisites for the establishment of a dictionary culture seems to exist among the respondents, notably the self-recognition of lexicographically relevant needs. If the results of this study could be general- 
ised for the population of school learners in Namibia, then the country is certainly ripe for the organised implementation of a dictionary culture by employing a broad framework like that of Klein (2007).

One of the focal areas for the implementation of a dictionary culture would indeed be at schools. At the moment, however, dictionary pedagogy in Namibian schools seems to be largely ineffective. This could probably be attributed to the lack of a reading culture prevailing in the country and not in the least among school teachers. Language teachers themselves have generally not been exposed to dictionary pedagogy either. It is therefore highly probable that the teaching of dictionary skills is grounded in the same deficient concepts of dictionaries that this study has revealed. (Re-)implementing dictionary pedagogy at schools would have to start with (a) in-service teacher training, (b) the inclusion of dictionary pedagogy in student teacher curricula, and (c) more detailed competency statements in the relevant school syllabuses.

Finally, as a result of the above, this study has shown that the planning of dictionary pedagogy at UNAM should assume no prior exposure to (effective) dictionary pedagogy, while the notion of meaning should not be assumed to be identical for all potential users and that dictionary pedagogy should take cognisance of this important aspect.

\section{Endnotes}

1. The authors are grateful to Ms Annelie van der Hoeven, Assistant Registrar: Academic Administration, for her assistance.

2. The system could determine that 978 first year students had completed their secondary education at a Namibian government school in 2008, but not all students who registered for their first year in 2009 necessarily completed their secondary education in 2008.

3. In the reproduced questionnaire in Addendum A, item numbers are indicated in italics and between brackets, e.g. (1).

\section{References}

Algeo, J. 1989. Dictionaries as Seen by the Educated Public in Great Britain and the USA. Hausmann, F.J. et al. (Eds.). 1989-1991: 28-34.

Atkins, B.T.S. and K. Varantola. 2008. Monitoring Dictionary Use. Fontenelle, T. (Ed.). 2008. Practical Lexicography. A Reader: 337-375. Oxford: Oxford University Press.

Atkins, B.T.S. and M. Rundell. 2008. The Oxford Guide to Practical Lexicography. Oxford: Oxford University Press.

Babbie, E. and J. Mouton (Eds.). 2001. The Practice of Social Research. Cape Town: Oxford University Press Southern Africa.

Barnhart, C.L. 1967. Problems in Editing Commercial Monolingual Dictionaries. Householder, F.W. and S. Saporta. (Eds.). 1967: 161-180.

Béjoint, H. 1981. The Foreign Student's Use of Monolingual English Dictionaries: A Study of Language Needs and Reference Skills. Applied Linguistics 2: 207-222. 
Béjoint, H. 1989. The Teaching of Dictionary Use: Present State and Future Tasks. Hausmann, F.J. et al. (Eds.). 1989-1991: 208-215.

Bergenholtz, H. and S. Tarp (Eds.). 1995. Manual of Specialised Lexicography. The Preparation of Specialised Dictionaries. Amsterdam/Philadelphia: John Benjamins.

Beyer, H.L. 2006. 'n Voorlopige model vir die sistematiese beskrywing van gebruikersvriendelikheid in woordeboeke. Lexikos 16: 46-66.

Beyer, H.L. 2010. Kontekstuele bepalers by die beplanning van skoolwoordeboeke. Lexikos 20: 5272.

Bogaards, P. 2003. Uses and Users of Dictionaries. Van Sterkenburg, P. (Ed.). 2003: 26-33.

Carstens, A. 1995. Language Teaching and Dictionary Use: An Overview. Lexikos 5: 105-116.

Du Plooy, G.M. 2009. Communication Research. Techniques, Methods and Applications. Second Edition. Cape Town: Juta.

Ekwa Ebanéga, G.-M. and F. Tomba Moussavou. 2008. A Survey of the Dictionary Use of Gabonese Students at Two South African Universities. Lexikos 18: 349-365.

Faul, A.K. 2008. Increasing Interactions with Nature: A Survey of Expectations on a University Campus. Urban Habitats 5(1): 58-83.

Gouws, R.H. and D.J. Prinsloo. 2005. Principles and Practice of South African Lexicography. Stellenbosch: SUN PReSS.

Gouws, R.H. 1989. Leksikografie. Pretoria/Cape Town: Academica.

Greenbaum, S., C.F. Meyer and J. Taylor. 1984. The Image of the Dictionary for American College Students. Dictionaries 6: 31-52.

Haacke, W.H.G. and E. Eiseb. 2002. A Khoekhoegowab Dictionary with an English Khoekhoegowab Index. Windhoek: Gamsberg Macmillan.

Hartmann, R.R.K. 1989. Sociology of the Dictionary User: Hypotheses and Empirical Studies. Hausmann, F.J. et al. (Eds.). 1989-1991: 102-111.

Hartmann, R.R.K. 2001. Teaching and Researching Lexicography. Essex: Pearson Education.

Hatherall, G. 1984. Studying Dictionary Use: Some Findings and Proposals. Hartmann, R.R.K. (Ed.). 1984. LEXeter '83 Proceedings: 183-189. Tübingen: Max Niemeyer.

Hausmann, F.J., O. Reichmann, H.E. Wiegand and L. Zgusta (Eds.). 1989-1991. Wörterbücher. Ein internationales Handbuch zur Lexikographie/Dictionaries. An International Encyclopedia of Lexicography/Dictionnaires. Encyclopédie internationale de lexicographie. Berlin/New York: Walter de Gruyter.

Householder, F.W. and S. Saporta (Eds.). 1967. Problems in Lexicography. Bloomington: Indiana University.

Jackson, H. 2002. Lexicography. An Introduction. London/New York: Routledge.

Kernerman, I.J. 2007. What's So Good or Bad about Advanced EFL Dictionaries? Gottlieb, H. and J.E. Mogensen (Eds.). 2007. Dictionary Visions, Research and Practice. Selected Papers from the 12th International Symposium on Lexicography, Copenhagen 2004: 139-145. Amsterdam/Philadelphia: John Benjamins.

Klein, J. 2007. Implementing a Dictionary Culture in South Africa: An Attempt at a General Framework for the African Languages. Lexikos 17: 416-423.

Landau, S.I. 2001. Dictionaries. The Art and Craft of Lexicography. Second Edition. Cambridge: Cambridge University Press.

Lew, R. 2002. Questionnaires in Dictionary Use Research: A Reexamination. Braasch, A. and C. Povlsen (Eds.). 2002. Proceedings of the Tenth EURALEX International Congress, EURALEX 
2002, Copenhagen, Denmark, August 12-17, 2002, Vol. 1: 267-271. Copenhagen: Center for Sprogteknologi, Copenhagen University.

Maho, J.F. 1998. Few People, Many Tongues. The Languages of Namibia. Windhoek: Gamsberg Macmillan.

Ministry of Basic Education and Culture. 2000. Upper Primary Phase Syllabus. Second Language Integrated English Syllabus. Grades 5-7. Okahandja: National Institute for Educational Development.

Ministry of Basic Education, Sport and Culture. 2004. The Curriculum for the Lower Primary Phase (Grades 1-4). Okahandja: National Institute for Educational Development.

Ministry of Education. 2005. Namibia Senior Secondary Certificate English Second Language Syllabus. Ordinary Level. Grades 11-12. Okahandja: National Institute for Educational Development.

Ministry of Education. 2006. Junior Secondary Phase English Second Language Syllabus. Grades 8-10. Okahandja: National Institute for Educational Development.

Ministry of Education and Culture. 1993. The Language Policy for Schools. 1992-1996 and Beyond. Windhoek: Ministry of Education and Culture.

Quirk, R. 1973. The Social Impact of Dictionaries in the UK. McDavid, R.I. and A.R. Duckert (Eds.). 1973. Lexicography in English: 76-83. New York: New York Academy of Sciences.

Siegel, M.E.A. 2007. What Do You Do with a Dictionary? A Study of Undergraduate Dictionary Use. Dictionaries 28: 23-47.

Svensén, B. 1993. Practical Lexicography. Principles and Methods of Dictionary-Making. Oxford: Oxford University Press.

Tarp, S. 2008. Lexicography in the Borderland between Knowledge and Non-Knowledge. General Lexicographical Theory with Particular Focus on Learner's Lexicography. Tübingen: Max Niemeyer.

Tarp, S. 2009. Reflections on Lexicographical User Research. Lexikos 19: 275-296.

Tötemeyer, A. 2010. Multilingualism and the Language Policy for Namibian Schools. Education in Fragile Contexts: Governance Practices and Challenges. Baden-Baden: Nomos.

Van Sterkenburg, P. 2003. 'The' Dictionary: Definition and History. Van Sterkenburg, P. (Ed.). 2003: 3-17. Amsterdam/Philadelphia: John Benjamins.

Van Sterkenburg, P. (Ed.). 2003. A Practical Guide to Lexicography. Amsterdam/Philadelphia: John Benjamins.

Whitcut, J. 1989. The Dictionary as a Commodity. Hausmann, F.J. et al. (Eds.). 1989-1991: 88-94.

Wiegand, H.E. 1977. Nachdenken über Wörterbücher. Aktuelle Probleme. Drosdowski, G., H. Henne and H.E. Wiegand. 1997. Nachdenken über Wörterbücher: 51-102. Mannheim/Vienna/ Zürich: Bibliographisches Institut. 
Addendum A: The questionnaire

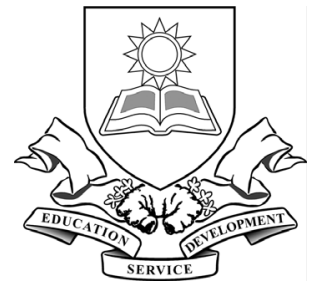

\section{The University of Namibia Dictionary Survey}

(1) $\begin{array}{ll}1 \_ & \text {FE } \\ 2 & \text { FEMS } \\ 3 & \text { FEN } \\ 4 \_ & \text {FHSS } \\ 5 \_ & \mathrm{FL} \\ 6 \_ & \text {FMHS }\end{array}$

This is a survey to find out what you think about dictionaries. You will not write your name on this questionnaire, so we will not know who answered on this page. Please try to be as honest as possible. There are no right or wrong answers. We just want to find out what students think about dictionaries in general.

Please write only in the white spaces or make an X where you are requested to do so.

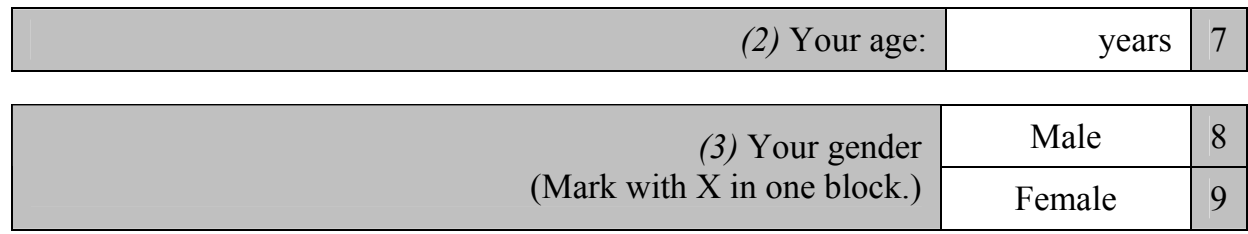

\begin{tabular}{|c|c|c|}
\hline \multirow{2}{*}{ (4) In which region did you complete Grade 12? } & Caprivi & 10 \\
\cline { 2 - 3 } & Erongo & 11 \\
\cline { 2 - 3 } & Hardap & 12 \\
\cline { 2 - 3 } & Karas & 13 \\
\cline { 2 - 3 } & Kavango & 14 \\
\cline { 2 - 3 } & Khomas & 15 \\
\cline { 2 - 3 } & Kunene & 16 \\
\cline { 2 - 3 } & Ohangwena & 17 \\
\cline { 2 - 3 } & Omaheke & 18 \\
\cline { 2 - 3 } & Omusati & 19 \\
\cline { 2 - 3 } & Oshana & 20 \\
\cline { 2 - 3 } & Otjikoto & 21 \\
\cline { 2 - 3 } & Otjozondjupa & 22 \\
\cline { 2 - 3 } & Not in Namibia & 23 \\
\hline
\end{tabular}




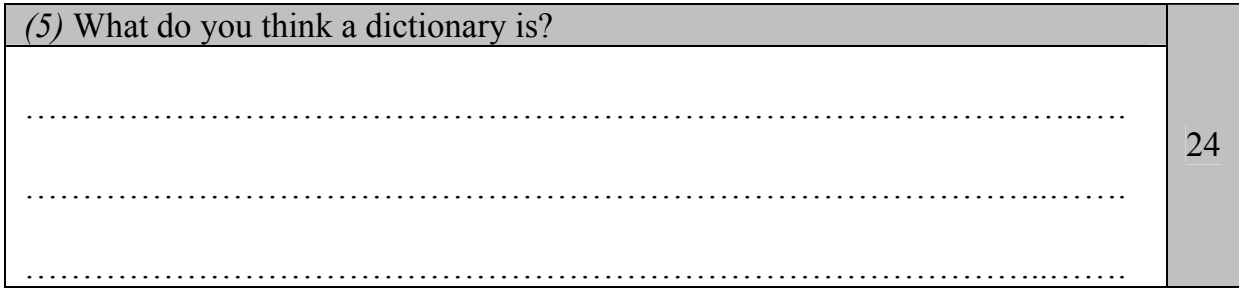

\begin{tabular}{|r|c|c|}
\hline \multirow{2}{*}{ (6) How often did you use a dictionary at school? } & Almost every day & 25 \\
\cline { 2 - 3 } (Mark with X in one block.) & Every week & 26 \\
\cline { 2 - 3 } & Once or twice a month & 27 \\
\cline { 2 - 3 } & Hardly ever & 28 \\
\hline
\end{tabular}

\begin{tabular}{|c|c|c|}
\hline \multirow{3}{*}{$\begin{array}{l}\text { Answer this question only } \\
\text { if you answered "Hardly } \\
\text { ever" to the previous } \\
\text { question: }\end{array}$} & There were no dictionaries available. & 29 \\
\hline & We were not allowed to use dictionaries in class. & 30 \\
\hline & $\begin{array}{l}\text { There was one or only a few dictionaries in } \\
\text { class, but I was afraid everyone would think I } \\
\text { was stupid if I asked to use a dictionary. }\end{array}$ & 31 \\
\hline $\begin{array}{l}\text { (7) Why did you never really } \\
\text { use a dictionary at school? }\end{array}$ & I do not know how to use a dictionary. & 32 \\
\hline (Mark with X in one block.) & $\begin{array}{l}\text { I did not need or find it necessary to use a } \\
\text { dictionary. }\end{array}$ & 3 \\
\hline
\end{tabular}

\begin{tabular}{|l|l|c|}
\hline \multirow{2}{*}{$\begin{array}{l}\text { (8) If you did use a } \\
\text { dictionary at school, what } \\
\text { kind of dictionary did you } \\
\text { use? }\end{array}$} & $\begin{array}{l}\text { A monolingual dictionary, e.g. an English } \\
\text { dictionary that explains the meanings of words } \\
\text { in English by using definitions. }\end{array}$ & $\begin{array}{l}\text { A bilingual dictionary, e.g. an English dictionary } \\
\text { that gives the translations of English words in } \\
\text { another language, like Afrikaans, Damara/Nama } \\
\text { or Oshiwambo. }\end{array}$ \\
\cline { 2 - 3 } & I don't know what kind of dictionary I used. & 35 \\
\cline { 2 - 3 } & I never really used a dictionary at school. & 36 \\
\hline
\end{tabular}

(9) If you did use a dictionary at school, what was the name of the dictionary that you used? If you can't remember, write "DON'T REMEMBER". 
(10) Did any teacher ever teach you how to use a dictionary? (Mark with $\mathrm{X}$ in one block.)

\begin{tabular}{|l|l|}
\hline Yes & 39 \\
\hline No & 40 \\
\hline
\end{tabular}

\begin{tabular}{|r|c|c|}
\hline $\begin{array}{c}\text { Answer this question only if you answered "Yes" to the } \\
\text { previous question: } \\
\text { (11) Which teacher taught you how to use a dictionary? }\end{array}$ & $\begin{array}{c}\text { One of my } \\
\text { (Manguage teachers }\end{array}$ & 41 \\
\cline { 2 - 3 } & Another teacher & 42 \\
\hline
\end{tabular}

(12) Do you have your own dictionary? (Mark with X in one block.)

\begin{tabular}{|l|l|}
\hline Yes & 43 \\
\hline No & 44 \\
\hline
\end{tabular}

John is a first year student at UNAM. Below are a number of questions that he is wondering about. Which of the questions do you think a dictionary would answer for John? If you think that a dictionary would provide the answer, mark the "Yes" block next to the relevant question. If you think that a dictionary would not provide the answer to a question, mark the "No" block next to the relevant question. If you don't know whether a dictionary would provide the answer, mark the "Don't know" block next to the relevant question.

(13) John is not sure how to spell the word psychologist.

Do you think a dictionary would provide the answer?

(Mark with X in one block.)

\begin{tabular}{|c|c|}
\hline Yes & 45 \\
\hline No & 46 \\
\hline Don't know & 47 \\
\hline
\end{tabular}

(14) John wonders how the weather will be like tomorrow.

Do you think a dictionary would provide the answer?

(Mark with $\mathrm{X}$ in one block.)

\begin{tabular}{|c|c|}
\hline Yes & 48 \\
\hline No & 49 \\
\hline Don't know & 50 \\
\hline
\end{tabular}

(15) John wonders what the meaning of the word courteous is.

Do you think a dictionary would provide the answer?

(Mark with $\mathrm{X}$ in one block.)

\begin{tabular}{|c|c|}
\hline Yes & 51 \\
\hline No & 52 \\
\hline Don't know & 53 \\
\hline
\end{tabular}

(16) John must prepare for a class presentation and he is not sure how to pronounce the word pterodactyl.

Do you think a dictionary would provide the answer?

(Mark with X in one block.)

\begin{tabular}{|c|c|}
\hline Yes & 54 \\
\hline No & 55 \\
\hline Don't know & 56 \\
\hline
\end{tabular}


(17) John wonders how much a hamburger costs.

Do you think a dictionary would provide the answer?

(Mark with $\mathrm{X}$ in one block.)

\begin{tabular}{|c|c|}
\hline Yes & 57 \\
\hline No & 58 \\
\hline Don't know & 59 \\
\hline
\end{tabular}

(18) John is writing and he is not sure where he can break off the word interesting at the end of a line. Is it inte-resting or interesting?

Do you think a dictionary would provide the answer?

(Mark with $\mathrm{X}$ in one block.)

\begin{tabular}{|c|c|}
\hline Yes & 60 \\
\hline No & 61 \\
\hline Don't know & 62 \\
\hline
\end{tabular}

(19) John wonders what the plural form of the word curriculum is. Is it curriculums or curricula?

Do you think a dictionary would provide the answer? (Mark with X in one block.)

\begin{tabular}{|c|c|}
\hline Yes & 63 \\
\hline No & 64 \\
\hline Don't know & 65 \\
\hline
\end{tabular}

(20) John reads the following sentence:

"When Lisa's car broke down, she knew she was a sitting duck."

John does not know the meaning of the expression she was a sitting duck. Do you think a dictionary would provide the answer?

(Mark with X in one block.)

\begin{tabular}{|c|c|}
\hline Yes & 66 \\
\hline No & 67 \\
\hline Don't know & 68 \\
\hline
\end{tabular}

(21) John is not sure what today's date is.

Do you think a dictionary would provide the answer?

(Mark with $\mathrm{X}$ in one block.)

\begin{tabular}{|c|c|}
\hline Yes & 69 \\
\hline No & 70 \\
\hline Don't know & 71 \\
\hline
\end{tabular}

(22) John is writing a birthday card for a friend. He is not sure whether he should write Congratulations on your birthday! or Congratulations with your birthday!

Do you think a dictionary would provide the answer? (Mark with $\mathrm{X}$ in one block.)

\begin{tabular}{|c|c|}
\hline Yes & 72 \\
\hline No & 73 \\
\hline Don't know & 74 \\
\hline
\end{tabular}

(23) John is writing a formal business letter to the Ministry of Education, and he is not sure whether he may use the word stuff in such a formal letter. Do you think a dictionary would provide the answer?

(Mark with X in one block.)

\begin{tabular}{|c|c|}
\hline Yes & 75 \\
\hline No & 76 \\
\hline Don't know & 77 \\
\hline
\end{tabular}

(24) John is not sure whether he should spell the word Christian with a capital letter. Is it $\underline{C}$ hristian or $\underline{c}$ hristian?

Do you think a dictionary would provide the answer?

(Mark with X in one block.)

\begin{tabular}{|c|c|}
\hline Yes & 78 \\
\hline No & 79 \\
\hline Don't know & 80 \\
\hline
\end{tabular}


(25) John wonders where the word biltong comes from. Do you think a dictionary would provide the answer?

(Mark with $\mathrm{X}$ in one block.)

\begin{tabular}{|c|c|} 
Yes & 81 \\
\hline No & 82 \\
\hline Don't know & 83 \\
\hline
\end{tabular}

(26) John wants to know what the telephone number of the nearest hospital is.

Do you think a dictionary would provide the answer?

(Mark with $\mathrm{X}$ in one block.)

\begin{tabular}{|c|c|}
\hline Yes & 84 \\
\hline No & 85 \\
\hline Don't know & 86 \\
\hline
\end{tabular}

(27) John is not sure what the past tense form of catch is.

Is it catched or caught?

Do you think a dictionary would provide the answer?

(Mark with $\mathrm{X}$ in one block.)

\begin{tabular}{|c|c|}
\hline Yes & 87 \\
\hline No & 88 \\
\hline Don't know & 89 \\
\hline
\end{tabular}

(28) John wonders why Christmas Day always falls on 25

December.

Do you think a dictionary would provide the answer?

(Mark with $\mathrm{X}$ in one block.)

\begin{tabular}{|c|c|}
\hline Yes & 90 \\
\hline No & 91 \\
\hline Don't know & 92 \\
\hline
\end{tabular}

(29) John wonders what the abbreviation VAT stands for.

Do you think a dictionary would provide the answer?

(Mark with $\mathrm{X}$ in one block.)

\begin{tabular}{|c|c|}
\hline Yes & 93 \\
\hline No & 94 \\
\hline Don't know & 95 \\
\hline
\end{tabular}

(30) John wonders what sound a cat makes:

Does a cat bark or does it meow?

Do you think a dictionary would provide the answer?

(Mark with $\mathrm{X}$ in one block.)

\begin{tabular}{|c|c|} 
Yes & 96 \\
\hline No & 97 \\
\hline Don't know & 98 \\
\hline
\end{tabular}

\begin{tabular}{l|c|c|}
\hline $\begin{array}{l}\text { (31) John wonders how many eggs are in a dozen: 10 eggs or 12 } \\
\text { eggs? }\end{array}$ & Yes & 99 \\
\cline { 2 - 3 } $\begin{array}{l}\text { Do you think a dictionary would provide the answer? } \\
\text { (Mark with X in one block.) }\end{array}$ & No & 100 \\
\cline { 2 - 3 } & Don't know & 101 \\
\hline
\end{tabular}

(32) John wants to know the distance between Windhoek and Oshakati.

Do you think a dictionary would provide the answer?

(Mark with $\mathrm{X}$ in one block.)

\begin{tabular}{|c|c|}
\hline Yes & 102 \\
\hline No & 103 \\
\hline Don't know & 104 \\
\hline
\end{tabular}


(33) John wonders whether the word critic is a verb or a noun. Do you think a dictionary would provide the answer?

(Mark with X in one block.)

\begin{tabular}{|c|c|}
\hline Yes & 105 \\
\hline No & 106 \\
\hline Don't know & 107 \\
\hline
\end{tabular}

(34) John wonders what the opposite of the word hot is.

Do you think a dictionary would provide the answer?

(Mark with $\mathrm{X}$ in one block.)

\begin{tabular}{|c|c|}
\hline Yes & 108 \\
\hline No & 109 \\
\hline Don't know & 110 \\
\hline
\end{tabular}

(35) John is looking for a synonym for the word nice.

Do you think a dictionary would provide the answer?

(Mark with $\mathrm{X}$ in one block.)

\begin{tabular}{|c|c|}
\hline Yes & 111 \\
\hline No & 112 \\
\hline Don't know & 113 \\
\hline
\end{tabular}

\begin{tabular}{|l|c|c|}
\hline $\begin{array}{l}\text { (36) John wants to find out how many books there are in the } \\
\text { UNAM library. }\end{array}$ & Yes & 114 \\
\cline { 2 - 3 } $\begin{array}{l}\text { Do you think a dictionary would provide the answer? } \\
\text { (Mark with X in one block.) }\end{array}$ & Don't know & 116 \\
\hline
\end{tabular}

(37) John wonders if the word bloody is a swearword. Do you think a dictionary would provide the answer?

(Mark with $\mathrm{X}$ in one block.)

\begin{tabular}{|c|c|}
\hline Yes & 117 \\
\hline No & 118 \\
\hline Don't know & 119 \\
\hline
\end{tabular}

(38) John wonders if he should put a comma before the word because in a sentence.

Do you think a dictionary would provide the answer? (Mark with $\mathrm{X}$ in one block.)

\begin{tabular}{|c|c|}
\hline Yes & 120 \\
\hline No & 121 \\
\hline Don't know & 122 \\
\hline
\end{tabular}

(39) John is not sure whether he should write I am sick or I is sick.

Do you think a dictionary would provide the answer?

(Mark with X in one block.)

\begin{tabular}{|c|c|}
\hline Yes & 123 \\
\hline No & 124 \\
\hline Don't know & 125 \\
\hline
\end{tabular}

Thank you very much for your cooperation! 
Addendum B: Summary of the results of questionnaire items 13 to 39

\begin{tabular}{|c|r|r|r|r|r|l|c|}
\hline Item no. & Yes \% & No \% & Don't know \% & n & \multicolumn{1}{c|}{$\boldsymbol{X}^{\mathbf{2}}$} & $\mathbf{d f}$ & $\mathbf{p}$ \\
\hline 13 & 87.8 & 9.6 & 2.6 & 502 & 675.0 & 2 & $<0.05$ \\
\hline 14 & 1.0 & 99.0 & 0.0 & 501 & 972.3 & 2 & $<0.05$ \\
\hline 15 & 98.8 & 0.2 & 1.0 & 501 & 966.4 & 2 & $<0.05$ \\
\hline 16 & 80.5 & 14.9 & 4.6 & 502 & 510.2 & 2 & $<0.05$ \\
\hline 17 & 1.6 & 97.4 & 1.0 & 501 & 925.5 & 2 & $<0.05$ \\
\hline 18 & 70.5 & 15.9 & 13.6 & 477 & 295.9 & 2 & $<0.05$ \\
\hline 19 & 89.7 & 4.6 & 5.7 & 476 & 680.8 & 2 & $<0.05$ \\
\hline 20 & 42.5 & 41.9 & 15.6 & 475 & 67.4 & 2 & $<0.05$ \\
\hline 21 & 1.9 & 97.5 & 0.6 & 476 & 881.5 & 2 & $<0.05$ \\
\hline 22 & 57.0 & 29.3 & 13.7 & 474 & 136.4 & 2 & $<0.05$ \\
\hline 23 & 50.1 & 37.5 & 12.4 & 475 & 104.8 & 2 & $<0.05$ \\
\hline 24 & 64.8 & 23.4 & 11.8 & 474 & 220.3 & 2 & $<0.05$ \\
\hline 25 & 51.4 & 33.3 & 15.3 & 478 & 93.9 & 2 & $<0.05$ \\
\hline 26 & 1.2 & 97.1 & 1.7 & 481 & 879.8 & 2 & $<0.05$ \\
\hline 27 & 89.4 & 7.7 & 2.9 & 479 & 678.1 & 2 & $<0.05$ \\
\hline 28 & 11.5 & 79.5 & 9.0 & 478 & 458.9 & 2 & $<0.05$ \\
\hline 29 & 80.6 & 9.8 & 9.6 & 478 & 479.4 & 2 & $<0.05$ \\
\hline 30 & 47.2 & 38.2 & 14.6 & 479 & 81.3 & 2 & $<0.05$ \\
\hline 31 & 43.6 & 48.9 & 7.5 & 479 & 145.6 & 2 & $<0.05$ \\
\hline 32 & 1.4 & 96.9 & 1.7 & 478 & 868.1 & 2 & $<0.05$ \\
\hline 33 & 91.8 & 4.4 & 3.8 & 478 & 736.3 & 2 & $<0.05$ \\
\hline 34 & 58.0 & 30.3 & 11.7 & 479 & 156.4 & 2 & $<0.05$ \\
\hline 35 & 70.4 & 17.6 & 12.0 & 493 & 307.0 & 2 & $<0.05$ \\
\hline 36 & 1.0 & 98.2 & 0.8 & 496 & 938.7 & 2 & $<0.05$ \\
\hline 37 & 63.3 & 22.3 & 14.4 & 494 & 205.0 & 2 & $<0.05$ \\
\hline 38 & 39.1 & 44.9 & 16.0 & 494 & 69.4 & 2 & $<0.05$ \\
\hline 39 & 53.7 & 36.6 & 9.7 & 494 & 145.4 & 2 & $<0.05$ \\
\hline & & & & & & & \\
\hline
\end{tabular}

